\title{
Neurology"
}

\section{Acute symptomatic seizures in cerebral venous thrombosis}

Lindgren E, MD ${ }^{1, *}$, Silvis $\mathrm{SM}, \mathrm{MD}^{2, *}$, Hiltunen $\mathrm{S}, \mathrm{MD}, \mathrm{PhD}^{3}$, Heldner MR, MD, $\mathrm{MSc}^{4}$, Serrano F, MD ${ }^{5}$, De Sciscio M, MD ${ }^{6}$, Zelano J, MD, $\mathrm{PhD}^{1}$, Zuurbier SM, MD, $\mathrm{PhD}^{2}$, Sánchez van Kammen M, MD², Mansour M, MD , Aguiar de Sousa D, MD, MSc, $\mathrm{PhD}^{8}$, Penas S, B.Hlth.Sci ${ }^{9}$, Al-Asady S, MD ${ }^{10}$, Ekizoglu E, MD ${ }^{11}$, Redfors P, MD, PhD ${ }^{1}$, Ahmed A, MD ${ }^{1}$, Yesilot N, MD ${ }^{11}$, Ghiasian M, MD ${ }^{7}$, Barboza MA, MD ${ }^{12}$, Arnao V, MD, $\mathrm{PhD}^{13}$, Aridon $\mathrm{P}$, $\mathrm{MD}^{13}$, Punter MNM, MD, $\mathrm{PhD}^{10}$, Ferro JM, MD, $\mathrm{PhD}^{8}$, Kleinig T, MD, $\mathrm{PhD}^{6}$, Arauz A, MD, $\mathrm{PhD}^{5}$, Tatlisumak T, MD, $\mathrm{PhD}^{1,3}$, Arnold M, MD ${ }^{4}$, Putaala J, MD, $\mathrm{PhD}^{3}$, Coutinho JM, MD, $\mathrm{PhD}^{2, * *}$, Jood K, MD, $\mathrm{PhD}^{1}$

${ }^{*}, * *$ These authors contributed equally to the manuscript.

Neurology® Published Ahead of Print articles have been peer reviewed and accepted for publication. This manuscript will be published in its final form after copyediting, page composition, and review of proofs. Errors that could affect the content may be corrected during these processes. 
1. Department of Clinical Neuroscience, Institute of Neuroscience and Physiology, Sahlgrenska Academy at University of Gothenburg and Department of Neurology, Sahlgrenska University Hospital, Gothenburg, Sweden

2. Department of Neurology, Amsterdam UMC, University of Amsterdam, Amsterdam, The Netherlands

3. Department of Neurology, Helsinki University Hospital and University of Helsinki, Helsinki, Finland

4. Department of Neurology, Inselspital, Bern University Hospital and University of Bern, Bern, Switzerland

5. National Institute of Neurology and Neurosurgery Manuel Velasco Suarez, Mexico-City, Mexico

6. Department of Neurology, Royal Adelaide, Hospitals and Department of Medicine, University of Adelaide, Adelaide, SA, Australia

7. Sina Hospital, Hamadan University of Medical Science, Hamadan, Iran

8. Department of Neurosciences and Mental Health (Neurology), Hospital de Santa Maria/CHULN; University of Lisbon, Lisbon, Portugal

9. Faculdade de Medicina, Universidade de Lisboa, Lisbon, Portugal

10. Manchester Centre for Clinical Neurosciences, Salford Royal NHS Foundation Trust, Manchester, United Kingdom

11. Department of Neurology, Istanbul Faculty of Medicine, Istanbul University, Istanbul, Turkey

12. Neurosciences Department, Hospital Dr. R.A. Calderón Guardia, CCSS, San José, Costa Rica 
13. Department of Biomedicine, Neuroscience and Advanced Diagnostics (Bi.N.D), University of Palermo, Palermo, Italy

Correspondence to: Turgut Tatlisumak, MD, PhD, turgut.tatlisumak@neuro.gu.se

Word count: 3072

Word count in abstract: 250

Character count title: 56

Number of references: 31

Number of tables: 3

Number of figures: 3

Supplemental data: Available from Dryad (Table e-1. Cerebral venous thrombosis consortium cohorts and inclusion periods; Table e-2. Characteristics of patients with acute symptomatic seizures up to 14 days after diagnosis of cerebral venous thrombosis; Table e-3. Risk factors for acute symptomatic seizures up to 14 days after diagnosis of cerebral venous thrombosis): https://doi.org/10.5061/dryad.w6m905am7

Statistical analyses: conducted by E Lindgren and SM Silvis

Key words: cerebral venous thrombosis; prediction; outcome; acute symptomatic seizure, status epilepticus

\section{Study Funding}

E Lindgren has received academic grants from The Swedish Neurological Society, Elsa and Gustav Lindh's Foundation, P-o Ahl's Foundation and Rune and Ulla Amlöv's Foundation for research on CVT. J Zelano has received academic grants from the Swedish Society of Medical Research (SSMF) for research on acquired epilepsy. T Tatlisumak has received 
academic grants from Sahlgrenska University Hospital and University of Gothenburg for research on CVT. M Arnold has received a Swiss Heart Foundation Grant for this study.

\section{Disclosures}

E Lindgren, S Silvis, S Hiltunen, M Heldner, F Serrano, and M De Sciscio, report no disclosures relevant to the manuscript.

J Zelano reports a consultancy fee from the Swedish Medical Product Agency, speaker honoraria from UCB, and has as an employee of Sahlgrenska University Hospital been investigator/subinvestigator in clinical trials sponsored by GW Pharma, Bial, UCB, and SK life science (no personal compensation).

S Zuurbier, M Sánchez van Kammen, M Mansour, D Aguiar de Sousa, S Penas, S Al-Asady, E Ekizoglu, P Redfors, A Ahmed, N Yesilot, M Ghiasian, M Barboza, V Arnao, and P Aridon report no disclosures relevant to the manuscript.

M Punter has received honorarium from Alexion Pharmaceuticals and has been investigator in a clinical trial sponsored by Lundbeck.

J Ferro, T Kleinig, A Arauz, T Tatlisumak, M Arnold, and J Putaala report no disclosures relevant to the manuscript.

JM Coutinho has received research funding for CVT research from Boehringer and Bayer. All fees were paid to JM Coutinho's institute (no personal compensation).

K Jood reports no disclosures relevant to the manuscript. 


\section{Abstract}

Objective: To identify characteristics, predictors, and outcomes of acute symptomatic seizures (ASS) in cerebral venous thrombosis (CVT), we investigated 1,281 consecutive adult patients with CVT included from 12 hospitals within the International CVT Consortium.

Methods: We defined ASS as any seizure between symptom onset and seven days after diagnosis of CVT. We stratified ASS into pre-diagnosis and solely post-diagnosis ASS. Status epilepticus (SE) was also analyzed separately. We analyzed predictors for ASS, and association between ASS and clinical outcome (modified Rankin Scale) with multivariable logistic regression.

Results: Of 1,281 eligible patients, 441 (34\%) had ASS. Baseline predictors for ASS were intracerebral hemorrhage ([ICH], adjusted odds ratio [aOR] 4.1, 95\% confidence interval [CI] 3.0-5.5), cerebral edema/infarction without ICH (aOR 2.8, 95\%CI 2.0-4.0), cortical vein thrombosis (aOR 2.1, 95\% CI 1.5-2.9), superior sagittal sinus thrombosis (aOR 2.0, 95\% CI 1.5-2.6), focal neurological deficit (aOR 1.9, 95\%CI 1.4-2.6), sulcal subarachnoid hemorrhage (aOR 1.6, 95\%CI 1.1-2.5) and female-specific risk factors (aOR 1.5, 95\%CI 1.12.1). Ninety-three (7\%) patients had solely post-diagnosis ASS, best predicted by cortical vein thrombosis (positive/negative predictive value 22\%/92\%). Eighty (6\%) patients had SE, independently predicted by $\mathrm{ICH}$, focal neurological deficits and cerebral edema/infarction. Neither ASS nor SE were independently associated with outcome.

Conclusion: ASS occurred in 1/3 of patients with CVT and was associated with brain parenchymal lesions and thrombosis of the superficial system. In absence of pre-diagnosis ASS, no subgroup was identified with sufficient risk of post-diagnosis ASS to justify 
prophylactic antiepileptic drug treatment. We found no association between ASS and outcome.

\section{Introduction}

Acute symptomatic seizures (ASS) are reported in $24-50 \%$ of patients with cerebral venous thrombosis (CVT) and can occur either before (pre-diagnosis ASS) or after CVT diagnosis (post-diagnosis ASS). ${ }^{1-3}$ Various risk factors for ASS have been identified, including focal neurological deficits, supratentorial parenchymal lesions, intracerebral hemorrhage (ICH), focal edema/ischemic infarction, superior sagittal sinus thrombosis, cortical vein thrombosis, and pregnancy or puerperium. ${ }^{2,4-8}$ However, data from large international cohorts are scarce and little is known about the risk of developing status epilepticus (SE). ${ }^{1,9}$ Although ASS may increase the risk of early death, ${ }^{5}$ occurrence of ASS has not been shown to be associated with poor long-term clinical outcome after CVT. ${ }^{1,9,10}$

To prevent further seizures, anti-epileptic drug (AED) treatment is recommended by the European and American guidelines on CVT in patients with ASS and supratentorial lesions. ${ }^{9,11}$ However, in the group of patients without seizures at the time of CVT diagnosis, no specific group has been identified with a high enough risk of subsequent post-diagnosis ASS to warrant primary prophylactic AED treatment. ${ }^{2,4,5,9,11}$

The aims of the current study were 1) to confirm previously identified risk factors and search for novel risk factors for ASS in a large cohort of CVT patients, 2) to investigate predictors for post-diagnosis seizures in the absence of pre-diagnosis seizures, in order to identify subgroups potentially benefitting from prophylactic AED treatment, 3) to investigate risk 
factors for the development of SE in the acute phase, and 4) to study the association between ASS and clinical outcome.

\section{Methods}

\section{$\underline{\text { Study design and patient selection }}$}

We used data from the International CVT Consortium, which is an ongoing collaboration between CVT research groups from 12 hospitals. ${ }^{12-14}$ Details of the consortium are described in the Supplemental data available from Dryad (Table e-1 doi:10.5061/dryad.w6m905qm7). Start of recruitment varied per hospital, the earliest being January 1990. We included adult patients diagnosed with CVT until December 2018. Patients with a history of epilepsy, eclampsia, or pre-eclampsia were excluded.

\section{$\underline{\text { Data collection and definitions }}$}

Data on demographics, type of symptom onset, baseline clinical characteristics, risk factors for thrombosis, laboratory investigations, imaging findings, treatment, and clinical outcome were recorded using a standardized case record form. Diagnosis of CVT was confirmed with CT-venography, MRI with MR-venography, catheter angiography, or autopsy, in accordance with international guidelines. ${ }^{11}$ We considered female-specific risk factors as any of the following: oral contraceptive use, hormone replacement therapy, pregnancy, or puerperium. Type of onset was categorized according to time from symptom onset to admission as acute 
onset (<48 hours), subacute onset (between 48 hours and 30 days), and chronic onset ( $>30$ days).

Seizures were diagnosed by treating physicians. We defined ASS as any seizure that occurred between symptom onset and seven days after diagnosis of CVT. ${ }^{15,16}$ We categorized seizures in accordance with the recommendations of the International League Against Epilepsy (ILAE) as focal or bilateral tonic-clonic seizures. We classified focal to bilateral tonic-clonic seizures as bilateral tonic-clonic seizures. ${ }^{17}$ Further, we defined SE as continuous seizure activity for five minutes or more, or multiple seizures within 30 minutes without normalization of consciousness in-between. ${ }^{18}$ Number of seizures was recorded as single or multiple and seizure recurrence was recorded up to seven days after diagnosis.

Patients with ASS were further subdivided according to the timing of the first seizure. Patients in whom the first seizure occurred prior to diagnosis of CVT were categorized as prediagnosis ASS, while patients in whom the first seizure occurred after diagnosis of CVT were categorized as post-diagnosis ASS.

With regard to the categorization of baseline radiological findings, intraparenchymal hemorrhages and hemorrhagic infarcts were clustered as intracerebral hemorrhage (ICH). The presence of cerebral edema/infarction without hemorrhage, subarachnoid hemorrhages (SAH), and subdural hematoma (SDH) were scored separately. We recorded the location of the intracerebral lesions as supratentorial and/or infratentorial, and cortical and/or subcortical.

Outcome was assessed using the modified Rankin Scale (mRS) and poor clinical outcome was defined as a score of 2 to 6 . For the outcome analysis we used the mRS score at last followup. Mortality was also analyzed separately. Patients who were followed-up for less than three months were excluded, except if they had died within three months. The Adelaide cohort did 
not collect functional outcome at follow-up and these patients were therefore excluded from the outcome analysis.

\section{$\underline{\text { Standard Protocol Approvals, Registration, and Patient Consents }}$}

Each center received permission from local authorities and ethics committees to collect observational data, and obtained written informed consent, when this was required under applicable national laws.

\section{Data Availability}

All study data are available upon reasonable request.

\section{$\underline{\text { Data analysis }}$}

We compared demographic, clinical features, risk factors for CVT, and imaging findings between patients with and without ASS. Associations between baseline characteristics and ASS were investigated using Fisher's exact test for dichotomous data and Mann Whitney U test for continuous data. We assessed potential predictors for ASS using multivariable logistic regression analysis. Three variables (supratentorial lesion, subcortical lesion and cortical lesion) were not considered eligible for multivariate analyses due to more than $5 \%$ missing data. Potential predictors were selected based on clinical plausibility and the univariable analysis ( $\mathrm{p}$-value <0.1): age, female sex, ICH, cerebral edema/infarct only, focal neurological deficit, sulcal SAH, superior sagittal sinus thrombosis, female-specific risk factor, and cortical vein thrombosis. An identical approach was used in three separate analyses with 1) postdiagnosis ASS, 2) SE, and 3) poor clinical outcome (mRS 2 to 6 at last follow-up at least 
three months after CVT diagnosis) as the dependent variables. For analysis on clinical outcome, we adjusted for factors associated with poor outcome in univariate analysis or previous literature; ${ }^{1}$ age, female sex, focal neurological deficits, coma, infection, ICH, subdural hematoma, sulcal SAH, and cancer. Odds ratios (OR) and 95\% confidence intervals (CI) were calculated. We compared clinical outcome between patients with pre-diagnosis ASS and patients with post-diagnosis ASS. We calculated positive predictive values (PPV) and negative predictive values (NPV) for post-diagnosis ASS separately for all variables with probability value below 0.1 in univariate analyses. We also performed a sensitivity analysis including ASS up to 14 days. ${ }^{2,4-7}$ All data were analyzed with IBM SPSS Statistics 23.0 (International Business Machines Corporation, New York).

\section{Results}

There were 1,308 adult patients diagnosed with CVT within the study period. After applying the exclusion criteria, 1,281 patients were included in the study (Figure 1). In total, 441 (34\%) patients had at least one ASS and of these, 348 patients (27\% of all patients, $79 \%$ of patients with ASS) had pre-diagnosis and 93 (7\% of all patients, $21 \%$ of patients with ASS) had solely post-diagnosis seizures. Focal seizures occurred in $187(15 \%)$ patients and tonic-clonic seizures in $325(25 \%)$ patients. In total, 266 patients (21\% of all patients, $60 \%$ of patients with ASS) suffered a recurrent ASS. Of eligible patients, data of 822 patients (64\%) were collected prospectively and 459 patients $(36 \%)$ retrospectively.

Baseline characteristics of patients with ASS and patients without ASS are presented in Table 1. Patients with ASS were more often of female sex and had more frequently acute onset, focal neurological deficits, or coma on admission. On baseline imaging, ICH, cerebral edema/infarction, sulcal SAH, and superior sagittal sinus thrombosis were more common 
findings among patients with ASS. Patients with ASS more often had supratentorial or cortical lesions compared to patients without ASS. Patients with ASS also had longer hospital stays, were more often admitted to an intensive care unit and were more often treated with anticoagulants. Among patients with ASS, $161(37 \%)$ patients received acute treatment with benzodiazepines and 217 (49\%) received intravenous AEDs. General anesthesia was administered in 61 (14\%) patients. Treatment with an AED was started in 410 patients (94\%) with ASS, most commonly phenytoin, levetiracetam or valproic acid (Table 1). Six of the patients who had ASS (1\%) had received prophylactic AED treatment before the first ASS. Among patients without ASS, two patients $(<1 \%)$ received prophylactic AED treatment.

\section{Predictors of ASS}

In the multivariable model, presented in Table 2, independent predictors of ASS were ICH, cerebral edema/infarct only, cortical vein thrombosis, superior sagittal sinus thrombosis, focal neurological deficits, sulcal SAH, and female-specific risk factors. An additional explorative analysis including ASS up to 14 days post CVT diagnosis yielded the same predictors and only gave a slightly higher estimate of the frequency of ASS, namely $35 \%$ (data available from Dryad [Tables e-2 and e-3 doi:10.5061/dryad.w6m905qm7]).

\section{$\underline{\text { Post-diagnosis seizures }}$}

There were 93 patients in whom the first ASS occurred after CVT diagnosis (post-diagnosis ASS). Time to first post-diagnosis ASS for patients without presenting seizure is described in Figure 2. In $32(34 \%)$ patients, post-diagnosis ASS occurred within the first 24 hours after diagnosis, and in $66(71 \%)$ within the first 48 hours after diagnosis. 
Table 1 compares the characteristics of patients with post-diagnosis ASS to patients without ASS. In multivariable analyses, predictors for post-diagnosis ASS were focal neurological deficit, ICH, cerebral edema/infarct only, superior sagittal sinus thrombosis, and cortical vein thrombosis (Table 2).

When calculating PPV and NPV for univariable predictors of post-diagnosis ASS, no variable achieved PPV over 25\%. Highest predictive values were obtained for the variables focal neurological deficit and cortical vein thrombosis where PPV for post-diagnosis ASS were $17 \%$ and $22 \%$, and NPV $97 \%$ and $92 \%$, respectively.

\section{Predictors of SE}

Eighty (18\% of those with ASS, $6 \%$ of the total cohort) patients developed SE in the acute phase and $70(88 \%)$ of the incidences of SE occurred within 24 hours after diagnosis of CVT. In 37 patients, the first seizure was a SE. In multivariable logistic regression analysis, ICH (aOR 4.8, 95\% CI 2.5-9.4), focal neurological deficits (aOR 4.7, 95\% CI 2.2-10.1), and cerebral edema/infarct only (aOR 3.1, 95\% CI 1.5-6.8) were predictors for SE.

\section{Clinical outcome}

Of the 1,281 patients, data of 1,106 (86\%) could be included in the outcome analysis. The Adelaide cohort $(\mathrm{n}=97)$ and an additional 78 patients were excluded because they were followed-up for less than three months. Included patients were younger (median age at CVT diagnosis was 40 vs. $44, \mathrm{p}=0.008)$, more often female ( $71 \%$ vs. $59 \%$, $\mathrm{p}=0.003)$, more often had had baseline focal neurological deficits (59\% vs. 39\%, p<0.001), ICH (34\% vs. 26\%, 
$\mathrm{p}=0.046)$, and were less frequently diagnosed with cancer ( $9 \%$ vs. $18 \%, \mathrm{p}=0.001)$, compared to excluded patients.

The distribution of the mRS score at last follow-up in patients with and without ASS is shown in Figure 3. Median duration of follow up was 12 months (IQR 6-25) in the group with ASS and 12 months (IQR 6-25) in the group without ASS (p=0.876). Poor clinical outcome (mRS 2 to 6) was more common in patients with ASS compared to those without ASS (42\% vs. $31 \%, \mathrm{p}<0.001$, Table 3). Mortality was not increased in patients with ASS (11\% vs. 9\%, $\mathrm{p}=0.345$ ). After adjustment for prognostic factors, the presence of ASS was not associated with poor clinical outcome or mortality (Table 3). Clinical outcome at last follow-up did not differ between patients with pre-diagnosis ASS and patients with post-diagnosis ASS (data not shown). There was also no association between SE and clinical outcome (data not shown).

\section{Discussion}

In this large international observational study, we found that approximately one in three patients with CVT suffers from ASS. We confirmed that focal neurological deficits, ICH, superior sagittal sinus thrombosis, and cortical vein thrombosis are predictors for ASS. ${ }^{2,4,5}$ In addition, we identified cerebral edema/infarction, sulcal SAH and female-specific risk factors as new independent predictors. ICH, focal neurological deficits and cerebral edema/infarction also predicted SE in the acute phase. No subgroup without pre-diagnosis seizures was found to have a risk of post-diagnosis ASS of more than 25\%. Neither ASS nor SE were independently associated with clinical outcome.

The occurrence of ASS in our cohort essentially matches previous reports with approximately

one third of the patients experiencing ASS. ${ }^{1-3}$ Some previous reports used a period of 0-14 
days for describing ASS. We used a limit of 7 days, in accordance with current recommendations. ${ }^{15,16}$ To facilitate comparability with previous studies, we tested whether 14 days as the upper limit lead to different findings, which it did not (data available from Dryad [Tables e-2 and e-3 doi:10.5061/dryad.w6m905qm7]).

The strength of the predictors for ASS corresponds to the results of three previous CVT cohort studies. ${ }^{2,4,5}$ However, in these studies, when both ICH and cerebral edema/infarction were present, patients were categorized separately in both categories, which potentially created an overlap between the two groups. We addressed this issue by separating patients with cerebral edema/infarction from patients with both ICH and cerebral edema/infarction, showing that cerebral edema/infarction alone also increases the risk of ASS after CVT. Accumulation of intracellular calcium, parenchymal structural damage or biochemical neuron damage as a cause of excitotoxic glutamate release secondary to hypoxia and ischemia have all been suggested as possible mechanisms for developing ASS after ischemic stroke. ${ }^{19}$ In patients with ICH or SAH, hemoglobin degradation products (such as iron) or blood-borne factors (such as thrombin) may trigger epileptogenesis. ${ }^{20}$ Not only the type of lesion, but also the location of the lesion seems to be important for development of ASS. Previous studies suggest that supratentorial lesions, and lesions anterior to the central sulcus are predictive of ASS. ${ }^{1,5}$ We found similar associations in our cohort, but were unable to include lesion location to the multivariable analysis due to missing data. Compared to all CVT patients, women with CVT are relatively younger. Young age has been suggested a risk factor for developing post stroke epilepsy, which partly could explain why female-specific risk factors increased the risk of ASS. ${ }^{21}$ In most animal models, estradiol increases excitability, whereas progesterone bears anticonvulsive properties. ${ }^{22}$ However, there is no evidence that the use of exogenous sex hormones (i.e. oral contraceptives) increases the risk of seizures in young adults without epilepsy. ${ }^{23}$ 
SE occurred in $6 \%$ of all patients and in $18 \%$ of patients with ASS, which confirms previously reported frequencies of SE ranging from 0.5 to $11 \%$ among all patients and 1 to $22 \%$ among patients with ASS. ${ }^{2,4,5,24} \mathrm{ICH}$, focal neurological deficits and cerebral edema/infarction were predictors for SE which resemble strong predictors of ASS.

In our study, one in ten patients who had not experienced a pre-diagnosis seizure, developed post-diagnosis ASS. This estimate is higher than in previous studies. In the Venoport study and International Study on Cerebral Vein and Dural Sinus Thrombosis (ISCVT), only 3\% and $4 \%$ of patients without presenting seizures developed post-diagnosis ASS, respectively. ${ }^{4,5}$ One explanation for the lower estimates in the ISCVT and Venoport studies could be that diagnostic delay has decreased over time. In our cohort, the median delay from symptom onset to diagnosis was four days, while this was seven days in the ISCVT. In the Venoport study, the median interval from symptom onset to diagnosis was not reported.

In absence of seizures, the European Stroke Organisation/European Academy of Neurology guidelines present no recommendation regarding prophylactic AED treatment, while the American Heart Association/American Stroke Association guidelines do not recommend routine use of AEDs in absence of seizures (Class III, level of evidence C). ${ }^{9,11}$ Further, there are no studies that show that primary prophylactic treatment with AEDs reduces the risk of ASS or SE in CVT. A few studies did find that prophylaxis decreases the risk of ASS in patients with severe traumatic brain injury ${ }^{25}$ and aneurysmal SAH. ${ }^{26}$ In patients with spontaneous ICH and arterial ischemic stroke, primary prophylactic use of AEDs is not recommended. $^{27,28}$ There is some evidence that AEDs reduce the risk of seizures in patients with spontaneous ICH in the acute phase, ${ }^{29}$ but the use of prophylactic AEDs, especially phenytoin, has also been associated with a worse clinical outcome. ${ }^{30,31}$ In our study, we could not identify a specific subgroup of patients without pre-diagnosis seizures that would be eligible for primary prophylactic AEDs, i.e. that had such a high risk to develop post- 
diagnosis ASS that the potential benefit from an AED could outweigh the risk of side effects. Moreover, the data from our study indicate that, if one would consider prescribing AEDs in patients with CVT, it needs to be administered as soon as possible after the diagnosis, since most patients developed post-diagnosis seizures, including SE, within 48 hours after diagnosis. In our study, choices of ASS treatments reflected use of intravenously available AEDs of which concentrations can easily be measured in serum guiding treatments.

Although one previous study reported an association between ASS and increased early mortality, ${ }^{5}$ we found no association between ASS nor SE and clinical outcome after adjustment for other prognostic variables. A possible explanation why other studies found an association is that these may not have properly adjusted for confounders. Some of the predictors of ASS, such as focal deficits and ICH, also increase the risk of poor outcome. Further, we found no difference between patients with pre-diagnosis ASS and patients with post-diagnosis ASS regarding clinical outcome, suggestive of comparable severity of epileptic activity between the two groups.

Several limitations of our study warrant comment. First, the main aim of this study, to identify predictors for ASS, was not a pre-defined question when cases were enrolled in the cohort and thus the study lacks predefinition of variables. Although all patients are consecutive, some of the data were collected retrospectively. Second, because most centers in the CVT consortium function as a tertiary referral center for CVT, we may have an overrepresentation of severe cases, and thus of seizures, in our cohort. Third, due to the observational design of the study and limited numbers of patients with ASS not receiving an AED, we were not able to assess treatment effects of AEDs. The assessment of AED treatment efficacy would require taking into account multiple potential confounding factors such as exact dosages, AED serum concentrations, treatment duration, and justifies a separate study to be answered properly. Finally, despite not being limited to clinical diagnosis alone, most seizures were diagnosed 
clinically and in lack of routine EEG monitoring, non-convulsive seizures could not be systematically investigated.

To summarize, our study shows that ASS occur in approximately one third of all patients with CVT. ICH, cerebral edema/infarction, cortical vein thrombosis, superior sagittal thrombosis, focal neurological deficit, sulcal SAH and female-specific risk factors were all predictors for ASS in CVT. Post-diagnosis ASS were common, but in absence of pre-diagnosis ASS, no risk factor sufficiently predicted the development of post-diagnosis seizures to justify primary prophylactic AED treatment. Predictors for development of SE in the acute phase resembled strong predictors for ASS and were ICH, focal neurological deficits and cerebral edema/infarction. Finally, we found no influence of ASS on functional outcome after three or more months in CVT patients.

\section{Acknowledgments}

The authors are grateful to Judith Klecki for assisting with English language editing. 


\section{Appendix 1: Authors}

\begin{tabular}{|c|c|c|}
\hline Name & Location & Contributions \\
\hline $\begin{array}{l}\text { Erik Lindgren, } \\
\text { MD }\end{array}$ & $\begin{array}{l}\text { Department of Clinical Neuroscience, Institute } \\
\text { of Neuroscience and Physiology, Sahlgrenska } \\
\text { Academy at University of Gothenburg and } \\
\text { Department of Neurology, Sahlgrenska } \\
\text { University Hospital, Gothenburg, Sweden }\end{array}$ & $\begin{array}{l}\text { Designed and } \\
\text { conceptualized the } \\
\text { study; analyzed the } \\
\text { data; major role in the } \\
\text { acquisition of data; }\end{array}$ \\
\hline $\begin{array}{l}\text { Suzanne M } \\
\text { Silvis, MD }\end{array}$ & $\begin{array}{l}\text { Department of Neurology, Amsterdam UMC, } \\
\text { University of Amsterdam, The Netherlands }\end{array}$ & $\begin{array}{l}\text { Designed and } \\
\text { conceptualized the } \\
\text { study; analyzed the } \\
\text { data; major role in the } \\
\text { acquisition of data; } \\
\text { drafted and reviewed } \\
\text { the manuscript for } \\
\text { intellectual content }\end{array}$ \\
\hline $\begin{array}{l}\text { Sini Hiltunen, } \\
\mathrm{MD}, \mathrm{PhD}\end{array}$ & $\begin{array}{l}\text { Department of Neurology, Helsinki University } \\
\text { Hospital and University of Helsinki, Helsinki, } \\
\text { Finland }\end{array}$ & $\begin{array}{l}\text { Major role in the } \\
\text { acquisition of data; } \\
\text { revised the } \\
\text { manuscript for } \\
\text { intellectual content }\end{array}$ \\
\hline Mirjam R & Department of Neurology, Inselspital, Bern & Major role in the \\
\hline
\end{tabular}




\begin{tabular}{|c|c|c|}
\hline $\begin{array}{l}\text { Heldner, MD, } \\
\text { MSc }\end{array}$ & $\begin{array}{l}\text { University Hospital and University of Bern, } \\
\text { Bern, Switzerland }\end{array}$ & $\begin{array}{l}\text { acquisition of data; } \\
\text { revised the } \\
\text { manuscript for } \\
\text { intellectual content }\end{array}$ \\
\hline $\begin{array}{l}\text { Fabiola } \\
\text { Serrano, MD }\end{array}$ & $\begin{array}{l}\text { National Institute of Neurology and } \\
\text { Neurosurgery Manuel Velasco Suarez, Mexico- } \\
\text { City, Mexico }\end{array}$ & $\begin{array}{l}\text { Major role in the } \\
\text { acquisition of data; } \\
\text { revised the }\end{array}$ \\
\hline $\begin{array}{l}\text { M de Scisco, } \\
\text { MD }\end{array}$ & $\begin{array}{l}\text { Department of Neurology, Royal } \\
\text { Hospitals and Department of Mec } \\
\text { University of Adelaide, Adelaide }\end{array}$ & $\begin{array}{l}\text { Major role in the } \\
\text { acquisition of data; } \\
\text { revised the } \\
\text { manuscript for } \\
\text { intellectual content }\end{array}$ \\
\hline $\begin{array}{l}\text { Johan Zelano, } \\
\mathrm{MD}, \mathrm{PhD}\end{array}$ & $\begin{array}{l}\text { Department of Clinical Neuroscience, Institute } \\
\text { of Neuroscience and Physiology, Sahlgrenska } \\
\text { Academy at University of Gothenburg and } \\
\text { Department of Neurology, Sahlgrenska } \\
\text { University Hospital, Gothenburg, Sweden }\end{array}$ & $\begin{array}{l}\text { Designed and } \\
\text { conceptualized the } \\
\text { study; interpreted } \\
\text { data; revised the } \\
\text { manuscript for } \\
\text { intellectual content }\end{array}$ \\
\hline $\begin{array}{l}\text { Susanna M. } \\
\text { Zuurbier, MD, } \\
\text { PhD }\end{array}$ & $\begin{array}{l}\text { Amsterdam University Medical Center, } \\
\text { Amsterdam, The Netherlands }\end{array}$ & $\begin{array}{l}\text { Major role in the } \\
\text { acquisition of data; } \\
\text { revised the } \\
\text { manuscript for } \\
\text { intellectual content }\end{array}$ \\
\hline
\end{tabular}




\begin{tabular}{|c|c|c|}
\hline $\begin{array}{l}\text { Mayte Sánchez } \\
\text { van Kammen, } \\
\text { MD }\end{array}$ & $\begin{array}{l}\text { Department of Neurology, Amsterdam UMC, } \\
\text { University of Amsterdam, The Netherlands }\end{array}$ & $\begin{array}{l}\text { Major role in the } \\
\text { acquisition of data; } \\
\text { revised the } \\
\text { manuscript for } \\
\text { intellectual content }\end{array}$ \\
\hline $\begin{array}{l}\text { Maryam } \\
\text { Mansour, MD }\end{array}$ & $\begin{array}{l}\text { Sina Hospital, Hamadan University of Medical } \\
\text { Science, Hamadan, Iran }\end{array}$ & $\begin{array}{l}\text { Major role in the } \\
\text { acquisition of data; }\end{array}$ \\
\hline $\begin{array}{l}\text { Diana Aguiar } \\
\text { de Sousa, MD, } \\
\text { MSc, PhD }\end{array}$ & $\begin{array}{l}\text { Department of Neurosciences and Mental } \\
\text { Health, Hospital de Santa Maria/CHULN; } \\
\text { University of Lisbon, Lisbon, Portugal }\end{array}$ & $\begin{array}{l}\text { Major role in the } \\
\text { acquisition of data; } \\
\text { revised the } \\
\text { manuscript for } \\
\text { intellectual content }\end{array}$ \\
\hline $\begin{array}{l}\text { Sara Penas, } \\
\text { MD }\end{array}$ & $\begin{array}{l}\text { Faculdade de Medicina, Universidade de Lisboa, } \\
\text { Lisbon, Portugal }\end{array}$ & $\begin{array}{l}\text { Major role in the } \\
\text { acquisition of data; } \\
\text { revised the } \\
\text { manuscript for } \\
\text { intellectual content }\end{array}$ \\
\hline $\begin{array}{l}\text { Saleem Al- } \\
\text { Asady }\end{array}$ & $\begin{array}{l}\text { Faculty of Biology, Medicine and Health, } \\
\text { Manchester Medical School, University of } \\
\text { Manchester, Manchester, United Kingdom }\end{array}$ & $\begin{array}{l}\text { Major role in the } \\
\text { acquisition of data; } \\
\text { revised the } \\
\text { manuscript for } \\
\text { intellectual content }\end{array}$ \\
\hline
\end{tabular}




\begin{tabular}{|c|c|c|}
\hline $\begin{array}{l}\text { Esme } \\
\text { Ekizoglu, MD }\end{array}$ & $\begin{array}{l}\text { Department of Neurology, Istanbul Faculty of } \\
\text { Medicine, Istanbul University, Istanbul, Turkey }\end{array}$ & $\begin{array}{l}\text { Major role in the } \\
\text { acquisition of data; } \\
\text { revised the } \\
\text { manuscript for } \\
\text { intellectual content }\end{array}$ \\
\hline $\begin{array}{l}\text { Petra Redfors, } \\
\mathrm{MD}, \mathrm{PhD}\end{array}$ & $\begin{array}{l}\text { Department of Clinical Neuroscience, Institute } \\
\text { of Neuroscience and Physiology, Sahlgrenska } \\
\text { Academy at University of Gothenburg and } \\
\text { Department of Neurology, Sahlgrenska } \\
\text { University Hospital, Gothenburg, Sweden }\end{array}$ & $\begin{array}{l}\text { Designed and } \\
\text { conceptualized the } \\
\text { study; interpreted } \\
\text { data; revised the } \\
\text { manuscript for } \\
\text { intellectual content }\end{array}$ \\
\hline $\begin{array}{l}\text { Awet Ahmed, } \\
\text { MD }\end{array}$ & $\begin{array}{l}\text { Department of Clinical Neuroscience, Institute } \\
\text { of Neuroscience and Physiology, Sahlgrenska } \\
\text { Academy at University of Gothenburg and } \\
\text { Department of Neurology, Sahlgrenska } \\
\text { University Hospital, Gothenburg, Sweden }\end{array}$ & $\begin{array}{l}\text { Major role in the } \\
\text { acquisition of data; } \\
\text { revised the } \\
\text { manuscript for } \\
\text { intellectual content }\end{array}$ \\
\hline $\begin{array}{l}\text { Nilufer } \\
\text { Yesilot, MD }\end{array}$ & $\begin{array}{l}\text { Department of Neurology, Istanbul Faculty of } \\
\text { Medicine, Istanbul University, Istanbul, Turkey }\end{array}$ & $\begin{array}{l}\text { Major role in the } \\
\text { acquisition of data; } \\
\text { revised the } \\
\text { manuscript for } \\
\text { intellectual content }\end{array}$ \\
\hline $\begin{array}{l}\text { Masoud } \\
\text { Ghiasian, MD, } \\
\text { PhD }\end{array}$ & $\begin{array}{l}\text { Sina Hospital, Hamadan University of Medical } \\
\text { Science, Hamadan, Iran }\end{array}$ & $\begin{array}{l}\text { Major role in the } \\
\text { acquisition of data; } \\
\text { revised the } \\
\text { manuscript for }\end{array}$ \\
\hline
\end{tabular}




\begin{tabular}{|c|c|c|}
\hline & & intellectual content \\
\hline $\begin{array}{l}\text { Miguel A } \\
\text { Barboza, MD, } \\
\text { PhD }\end{array}$ & $\begin{array}{l}\text { Neurosciences Department, Hospital Dr. R.A. } \\
\text { Calderón Guardia, CCSS, San José, Costa Rica }\end{array}$ & $\begin{array}{l}\text { Major role in the } \\
\text { acquisition of data; } \\
\text { revised the } \\
\text { manuscript for } \\
\text { intellectual content }\end{array}$ \\
\hline $\begin{array}{l}\text { Valencia } \\
\text { Arnao, MD, } \\
\text { PhD }\end{array}$ & $\begin{array}{l}\text { Department of Biomedicine, Neuroscience and } \\
\text { Advanced Diagnostics (Bi.N.D), University of } \\
\text { Palermo, Palermo, Italy }\end{array}$ & $\begin{array}{l}\text { Major role in the } \\
\text { acquisition of data; } \\
\text { revised the }\end{array}$ \\
\hline $\begin{array}{l}\text { Aridon } \mathrm{P}, \mathrm{MD} \text {, } \\
\mathrm{PhD}\end{array}$ & $\begin{array}{l}\text { Department of Biomedicine, Neuroscience and } \\
\text { Advanced Diagnostics (Bi.N.D), University of } \\
\text { Palermo, Palermo, Italy }\end{array}$ & $\begin{array}{l}\text { Interpreted the data; } \\
\text { revised the } \\
\text { manuscript for } \\
\text { intellectual content }\end{array}$ \\
\hline $\begin{array}{l}\text { Martin NM } \\
\text { Punter, MD, } \\
\text { PhD }\end{array}$ & $\begin{array}{l}\text { Manchester Centre for Clinical Neurosciences, } \\
\text { Salford Royal NHS Foundation Trust, } \\
\text { Manchester, United Kingdom }\end{array}$ & $\begin{array}{l}\text { Major role in the } \\
\text { acquisition of data; } \\
\text { interpreted the data; } \\
\text { revised the } \\
\text { manuscript for } \\
\text { intellectual content }\end{array}$ \\
\hline $\begin{array}{l}\text { José M Ferro, } \\
\mathrm{MD}, \mathrm{PhD}\end{array}$ & $\begin{array}{l}\text { Department of Neurosciences and Mental } \\
\text { Health, Hospital de Santa Maria/CHULN; } \\
\text { University of Lisbon, Lisbon, Portugal }\end{array}$ & $\begin{array}{l}\text { Major role in the } \\
\text { acquisition of data; } \\
\text { interpreted the data; } \\
\text { revised the }\end{array}$ \\
\hline
\end{tabular}




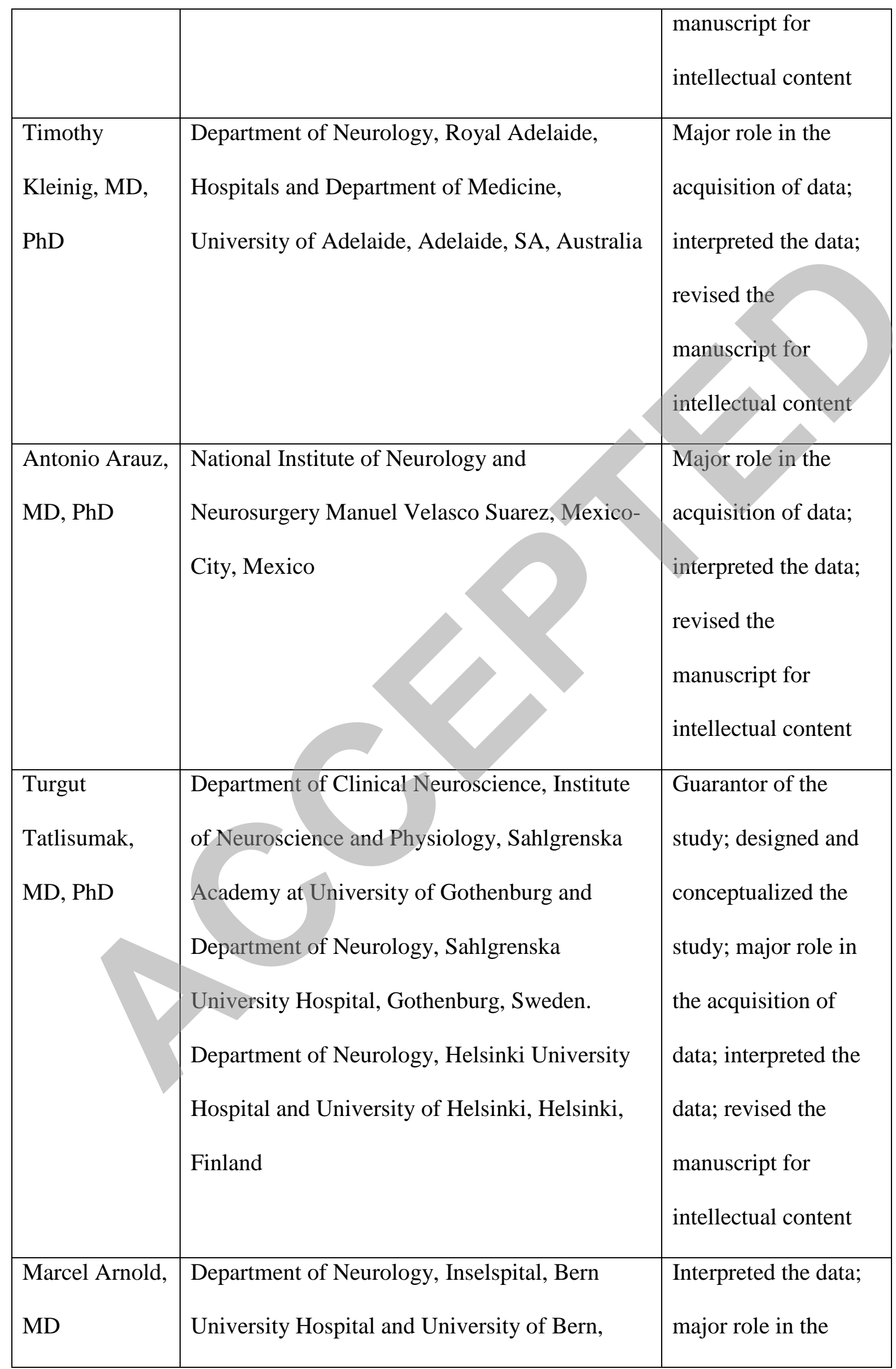




\begin{tabular}{|c|c|c|}
\hline & Bern, Switzerland & $\begin{array}{l}\text { acquisition of data; } \\
\text { revised the } \\
\text { manuscript for } \\
\text { intellectual content }\end{array}$ \\
\hline $\begin{array}{l}\text { Jukka Putaala, } \\
\mathrm{MD}, \mathrm{PhD}\end{array}$ & $\begin{array}{l}\text { Department of Neurology, Helsinki University } \\
\text { Hospital and University of Helsinki, Helsinki, } \\
\text { Finland }\end{array}$ & $\begin{array}{l}\text { Interpreted the data; } \\
\text { major role in the } \\
\text { acquisition of data; }\end{array}$ \\
\hline $\begin{array}{l}\text { Jonathan M } \\
\text { Coutinho, MD, } \\
\mathrm{PhD}\end{array}$ & $\begin{array}{l}\text { Department of Neurology, Amsterdam UMC, } \\
\text { University of Amsterdam, The Netherlands }\end{array}$ & $\begin{array}{l}\text { Designed and } \\
\text { conceptualized the } \\
\text { study; major role in } \\
\text { the acquisition of } \\
\text { data; interpreted the } \\
\text { data; revised the } \\
\text { manuscript for } \\
\text { intellectual content }\end{array}$ \\
\hline $\begin{array}{l}\text { Katarina Jood, } \\
\mathrm{MD}, \mathrm{PhD}\end{array}$ & $\begin{array}{l}\text { Department of Clinical Neuroscience, Institute } \\
\text { of Neuroscience and Physiology, Sahlgrenska } \\
\text { Academy at University of Gothenburg and } \\
\text { Department of Neurology, Sahlgrenska } \\
\text { University Hospital, Gothenburg, Sweden }\end{array}$ & $\begin{array}{l}\text { Designed and } \\
\text { conceptualized the } \\
\text { study; major role in } \\
\text { the acquisition of } \\
\text { data; interpreted the } \\
\text { data; revised the } \\
\text { manuscript for }\end{array}$ \\
\hline
\end{tabular}


Lindgren E, Silvis SM et al. Page 25 of 35

\begin{tabular}{|l|l|l|}
\hline & intellectual content \\
\hline
\end{tabular}




\section{References}

1. Ferro JM, Canhao P, Stam J, Bousser MG, Barinagarrementeria F, Investigators I. Prognosis of cerebral vein and dural sinus thrombosis: results of the International Study on Cerebral Vein and Dural Sinus Thrombosis (ISCVT). Stroke. 2004;35(3):664-670.

2. Masuhr F, Busch M, Amberger N, et al. Risk and predictors of early epileptic seizures in acute cerebral venous and sinus thrombosis. European journal of neurology. 2006;13(8):852-856.

3. Duman T, Uluduz D, Midi I, et al. A Multicenter Study of 1144 Patients with Cerebral Venous Thrombosis: The VENOST Study. J Stroke Cerebrovasc Dis. 2017;26(8):1848-1857.

4. Ferro JM, Canhao P, Bousser MG, Stam J, Barinagarrementeria F, Investigators I. Early seizures in cerebral vein and dural sinus thrombosis: risk factors and role of antiepileptics. Stroke. 2008;39(4):1152-1158.

5. Ferro JM, Correia M, Rosas MJ, Pinto AN, Neves G, Cerebral Venous Thrombosis Portuguese Collaborative Study G. Seizures in cerebral vein and dural sinus thrombosis. Cerebrovasc Dis. 2003;15(1-2):78-83.

6. Davoudi V, Keyhanian K, Saadatnia M. Risk factors for remote seizure development in patients with cerebral vein and dural sinus thrombosis. Seizure. 2014;23(2):135-139.

7. Mahale R, Mehta A, John AA, et al. Acute seizures in cerebral venous sinus thrombosis: What predicts it? Epilepsy research. 2016;123:1-5.

8. Li H, Cui L, Chen Z, Chen Y. Risk factors for early-onset seizures in patients with cerebral venous sinus thrombosis: A meta-analysis of observational studies. Seizure. 2019;72:33-39.

9. Ferro JM, Bousser MG, Canhao P, et al. European Stroke Organisation guideline for the diagnosis and treatment of cerebral venous thrombosis - endorsed by the European Academy of Neurology. European journal of neurology. 2017;24(10):1203-1213.

10. Canhão P, Ferro JM, Lindgren AG, Bousser MG, Stam J, Barinagarrementeria F. Causes and predictors of death in cerebral venous thrombosis. Stroke. 2005;36(8):1720-1725.

11. Saposnik G, Barinagarrementeria F, Brown RD, Jr., et al. Diagnosis and management of cerebral venous thrombosis: a statement for healthcare professionals from the American Heart Association/American Stroke Association. Stroke. 2011;42(4):1158-1192.

12. Silvis SM, Lindgren E, Hiltunen S, et al. Postpartum Period Is a Risk Factor for Cerebral Venous Thrombosis. Stroke. 2019;50(2):501-503.

13. Silvis SM, Hiltunen S, Lindgren E, et al. Cancer and risk of cerebral venous thrombosis: a case-control study. Journal of thrombosis and haemostasis : JTH. 2018;16(1):90-95.

14. Zuurbier SM, Hiltunen S, Lindgren E, et al. Cerebral Venous Thrombosis in Older Patients. Stroke. 2018;49(1):197-200.

15. Thurman DJ, Beghi E, Begley CE, et al. Standards for epidemiologic studies and surveillance of epilepsy. Epilepsia. 2011;52 Suppl 7:2-26.

16. Beghi E, Carpio A, Forsgren L, et al. Recommendation for a definition of acute symptomatic seizure. Epilepsia. 2010;51(4):671-675.

17. Fisher RS, Cross JH, French JA, et al. Operational classification of seizure types by the International League Against Epilepsy: Position Paper of the ILAE Commission for Classification and Terminology. Epilepsia. 2017;58(4):522-530.

18. Trinka E, Cock H, Hesdorffer D, et al. A definition and classification of status epilepticus-Report of the ILAE Task Force on Classification of Status Epilepticus. Epilepsia. 2015;56(10):1515-1523.

19. Bladin CF, Alexandrov AV, Bellavance A, et al. Seizures After Stroke: A Prospective Multicenter Study. JAMA neurology. 2000;57(11):1617-1622.

20. Silverman IE, Restrepo L, Mathews GC. Poststroke Seizures. JAMA neurology. 2002;59(2):195-201.

21. Graham NS, Crichton S, Koutroumanidis M, Wolfe CD, Rudd AG. Incidence and associations of poststroke epilepsy: the prospective South London Stroke Register. Stroke. 2013;44(3):605-611.

22. Scharfman HE, MacLusky NJ. The influence of gonadal hormones on neuronal excitability, seizures, and epilepsy in the female. Epilepsia. 2006;47(9):1423-1440.

23. Beier CP, Garcia Rodriguez LA, Saez ME, Gaist D, Gonzalez-Perez A. Hormonal contraception is not associated with increased risk for seizures in the general population: results from a cohort study using The Health Improvement Network. Eur J Clin Pharmacol. 2018;74(9):1175-1180. 
24. Kalita J, Chandra S, Misra UK. Significance of seizure in cerebral venous sinus thrombosis. Seizure. 2012;21(8):639-642.

25. Chang BS, Lowenstein DH, Quality Standards Subcommittee of the American Academy of N. Practice parameter: antiepileptic drug prophylaxis in severe traumatic brain injury: report of the Quality Standards Subcommittee of the American Academy of Neurology. Neurology. 2003;60(1):10-16.

26. Connolly ES, Jr., Rabinstein AA, Carhuapoma JR, et al. Guidelines for the management of aneurysmal subarachnoid hemorrhage: a guideline for healthcare professionals from the American Heart Association/american Stroke Association. Stroke. 2012;43(6):1711-1737.

27. Hemphill JC, 3rd, Greenberg SM, Anderson CS, et al. Guidelines for the Management of Spontaneous Intracerebral Hemorrhage: A Guideline for Healthcare Professionals From the American Heart Association/American Stroke Association. Stroke. 2015;46(7):2032-2060.

28. Powers WJ, Rabinstein AA, Ackerson T, et al. 2018 Guidelines for the Early Management of Patients With Acute Ischemic Stroke: A Guideline for Healthcare Professionals From the American Heart Association/American Stroke Association. Stroke. 2018;49(3):e46-e110.

29. Passero S, Rocchi R, Rossi S, Ulivelli M, Vatti G. Seizures after spontaneous supratentorial intracerebral hemorrhage. Epilepsia. 2002;43(10):1175-1180.

30. Messe SR, Sansing LH, Cucchiara BL, et al. Prophylactic antiepileptic drug use is associated with poor outcome following ICH. Neurocrit Care. 2009;11(1):38-44.

31. Naidech AM, Garg RK, Liebling S, et al. Anticonvulsant use and outcomes after intracerebral hemorrhage. Stroke. 2009;40(12):3810-3815.

\section{Figure 1: Flowchart of patient selection}

Patients in whom the first seizure occurred prior to diagnosis of CVT were categorized as pre-diagnosis ASS, while patients in whom the first seizure occurred after diagnosis of CVT were categorized as post-diagnosis ASS.

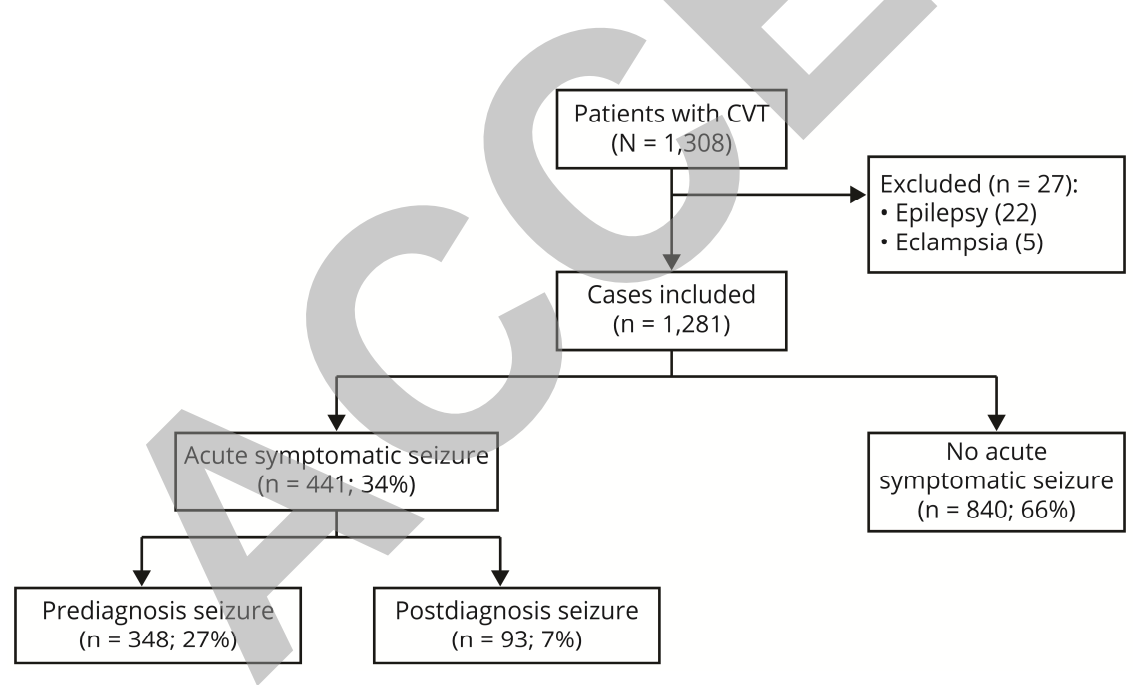


Figure 2: Time to first post-diagnosis acute symptomatic seizure

Number of patients ( $n=93)$ experiencing a first post-diagnosis acute symptomatic seizure, fractionated per day after diagnosis of cerebral venous thrombosis.

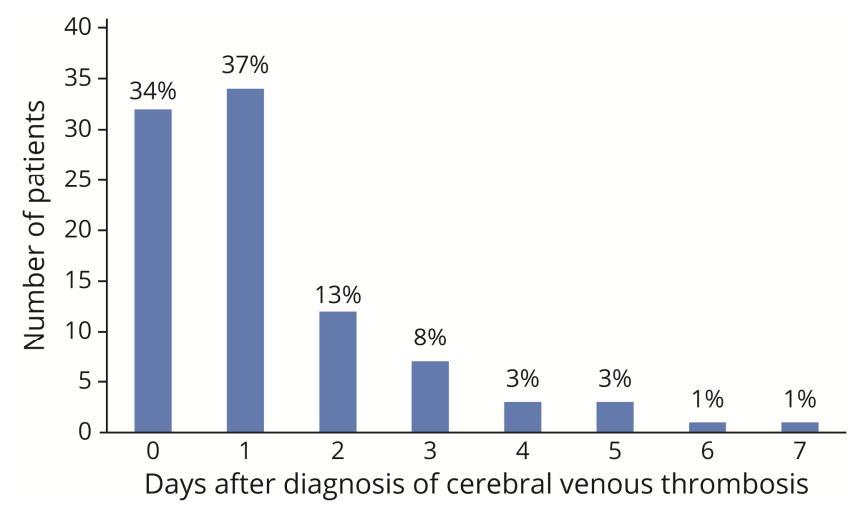

Figure 3: Distribution of $\mathrm{mRS}$ scores at last follow-up for patients with and without acute symptomatic seizures

Abbreviations: $m R S=$ modified Rankin Scale; $A S S=$ acute symptomatic seizures

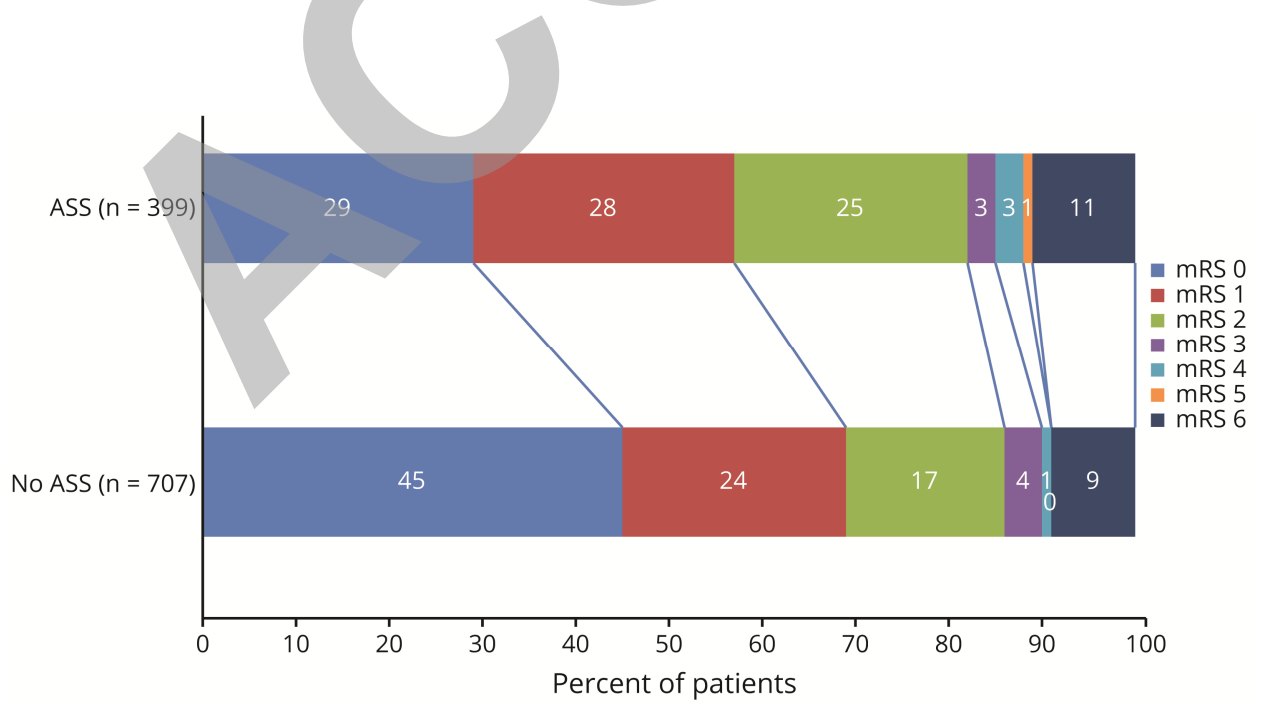




\begin{tabular}{|c|c|c|c|}
\hline No acute & Acute & P-value ${ }^{\mathbf{a}}$ & Solely post- \\
\hline symptomatic & symptomatic & & diagnosis \\
\hline seizures & seizures & & seizures \\
\hline $\mathrm{n}=840$ (ref) & $\mathrm{n}=441$ & & $\mathrm{n}=93$ \\
\hline
\end{tabular}

\section{Clinical characteristics}

Women, n/N (\%)

Age in years - median $(\mathrm{IQR})^{\mathrm{b}}$

Acute symptom onset <48 hours, n/N (\%)

Focal neurological deficits, n/N (\%)

Coma $(\mathrm{GCS}<9), \mathrm{n} / \mathrm{N}(\%)$

Risk factors, $\mathrm{n} / \mathrm{N}(\%)$

Oral contraceptive use ${ }^{c}$

Pregnancy, puerperium ${ }^{c}$

Hormone replacement therapy ${ }^{\mathrm{c}}$

Any female-specific risk factor ${ }^{c}$

Cancer

Infection

\section{Imaging characteristics, $\mathrm{n} / \mathrm{N}(\%)$}

Any parenchymal lesion

Intracerebral hemorrhage

Cerebral edema/infarct only

Lesion location $^{\mathrm{d}}$

Supratentorial

Cortical lesion

$\begin{array}{lll}559 / 840(67 \%) & 324 / 441(74 \%) & 0.011 \\ 41(30-53) & 40(29-52) & 0.280\end{array}$

$77 / 93(83 \%)$

0.001

$36(26-47)$

0.015

$240 / 808(30 \%)$

$167 / 431(39 \%) \quad 0.001$

$31 / 91(34 \%)$

0.400

$385 / 835(46 \%)$

$328 / 441(74 \%)<0.001$

$29 / 834(4 \%)$

41/439 (9\%)

$<0.001$

$5 / 93(5 \%) \quad 0.376$

$5 / 93(5 \%) \quad 0.376$

$79 / 93(85 \%)<0.001$

$225 / 554(41 \%)$

$139 / 322(43 \%) \quad 0.477$

$36 / 76(47 \%)$

0.267

$56 / 559(10 \%)$

$49 / 324(15 \%)$

0.031

$11 / 77(14 \%)$

0.239

$22 / 559(4 \%)$

$15 / 323(5 \%)$

0.606

$1 / 77(1 \%)$

0.342

$308 / 557(55 \%)$

$200 / 324(62 \%) \quad 0.066$

46/77 (60\%)

0.541

$88 / 836(11 \%)$

$43 / 440(10 \%) \quad 0.699$

10/93 (11\%)

0.861

$101 / 834(12 \%)$

$50 / 441(11 \%)$

0.716

$13 / 93(14 \%)$

0.617

$\begin{array}{lllll}328 / 839(39 \%) & 337 / 441(76 \%) & <0.001 & 70 / 93(75 \%) & <0.001 \\ 187 / 840(22 \%) & 228 / 441(52 \%) & <0.001 & 43 / 93(46 \%) & <0.001 \\ 128 / 840(15 \%) & 101 / 441(23 \%) & 0.001 & 24 / 93(26 \%) & 0.012\end{array}$

$264 / 668(40 \%) \quad 288 / 378(76 \%) \quad<0.001$

$65 / 86(76 \%)<0.001$

$171 / 658(26 \%) \quad 210 / 351(60 \%) \quad<0.001$

$52 / 83(63 \%)$

$<0.001$ 
Subcortical lesion

Sulcal subarachnoid hemorrhage

Subdural hematoma

Superior sagittal sinus thrombosis

Lateral sinus thrombosis

Cortical vein thrombosis

Straight sinus thrombosis

\section{Treatment and admission}

Hospital stay in days (median, IQR)

Anticoagulation, n/N (\%)

Decompressive hemicraniectomy, $\mathrm{n} / \mathrm{N}$

Endovascular treatment, $\mathrm{n} / \mathrm{N}(\%)$

Type of antiepileptic drug treatment

among patients with ASS, n/N (\%)

Phenytoin

Levetiracetam

Valproic acid

Carbamazepine

Other

Combination

No AED treatment
$9(6-14)$

$86 / 756(11 \%)$

$761 / 837(91 \%)$

$38 / 838(5 \%)$

$\begin{array}{lllll}96 / 657(15 \%) & 67 / 351(19 \%) & 0.073 & 13 / 82(16 \%) & 0.742 \\ 59 / 839(7 \%) & 73 / 441(17 \%) & <0.001 & 11 / 93(12 \%) & 0.099 \\ 19 / 838(2 \%) & 13 / 441(3 \%) & 0.457 & 0 / 93(0 \%) & 0.245\end{array}$

$364 / 836(44 \%) \quad 284 / 441(64 \%) \quad<0.001 \quad 67 / 93(73 \%) \quad<0.001$

$607 / 838(72 \%) \quad 256 / 440(58 \%) \quad<0.001 \quad 60 / 93(65 \%) \quad 0.115$

$104 / 838(12 \%) \quad 139 / 441(32 \%) \quad<0.001 \quad 30 / 93(32 \%) \quad<0.001$

$159 / 837(19 \%) \quad 47 / 441(11 \%) \quad<0.001 \quad 10 / 93(11 \%) \quad 0.064$

$12(8-18)<0.001<14(9-19)<0.001$

$138 / 439(31 \%)<0.001 \quad 27 / 93(29 \%)<0.001$

$422 / 441(96 \%) \quad 0.002 \quad 87 / 93(94 \%) \quad 0.562$

$24 / 441(5 \%) \quad 0.149 \quad 4 / 93(4 \%) \quad 0.772$

$25 / 441(6 \%) \quad 0.415 \quad 4 / 93(4 \%) \quad 0.772$
$182 / 432(42)$

$150 / 433(35)$

$108 / 432(25)$

$52 / 433(12)$

$30 / 433(7)$

$103 / 435(24)$

$26 / 433(6)$

Abbreviations: $I Q R=$ interquartile range; $G C S=$ Glasgow coma scale. ${ }^{a}$ Compared to no acute symptomatic seizures; ${ }^{b}$ No missing data $;{ }^{c}$ Percentage of women; ${ }^{d}$ Data are missing from two centers, $n=317$ 
Table 2: Predictors for acute symptomatic seizures and post-diagnosis seizures

\begin{tabular}{lll}
\hline & $\begin{array}{l}\text { Acute symptomatic seizures, } \\
\text { adjusted OR, (95\% CI) }\end{array}$ & Post-diagnosis seizures, \\
& $1.0(1.0-1.0)^{a}$ & $1.0(1.0-1.0)^{b}$ \\
\hline Age & $1.0(0.7-1.4)$ & $1.8(1.0-3.3)^{c}$ \\
Female sex & $4.1(3.0-5.5)$ & $2.8(1.6-4.8)$ \\
Intracerebral hemorrhage & $2.8(2.0-4.0)$ & $2.3(1.3-4.4)$ \\
Cerebral edema/infarct only & $2.1(1.5-2.9)$ & $2.5(1.5-4.2)$ \\
Superior sagittal thrombosis & $2.0(1.5-2.6)$ & $2.2(1.3-3.7)$ \\
Focal neurological deficit & $1.9(1.4-2.6)$ & $4.1(2.2-7.5)$ \\
Sulcal subarachnoid hemorrhage & $1.6(1.1-2.5)$ & $1.0(0.5-2.1)$ \\
Female-specific risk factors & $1.5(1.1-2.1)$ & $\mathrm{N} / \mathrm{A}$
\end{tabular}


Table 3: Clinical outcome

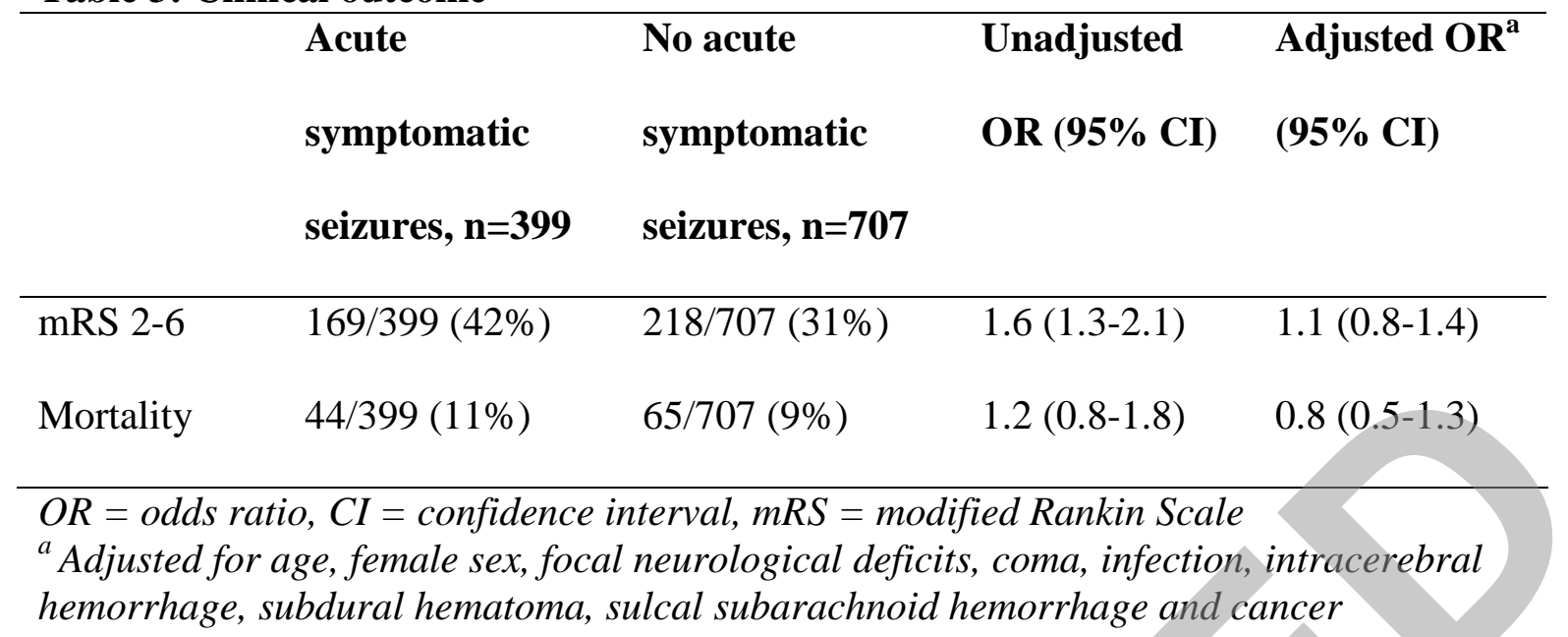




\section{Neurology}

\section{Acute symptomatic seizures in cerebral venous thrombosis \\ Erik Lindgren, Suzanne M. Silvis, Sini Hiltunen, et al. \\ Neurology published online August 5, 2020 \\ DOI 10.1212/WNL.0000000000010577}

This information is current as of August 5, 2020

\section{Updated Information \& Services \\ Subspecialty Collections}

Permissions \& Licensing

Reprints including high resolution figures, can be found at: http://n.neurology.org/content/early/2020/08/05/WNL.0000000000010 577.full

This article, along with others on similar topics, appears in the following collection(s):

All Epilepsy/Seizures

http://n.neurology.org/cgi/collection/all_epilepsy_seizures

Cerebral venous thrombosis

http://n.neurology.org/cgi/collection/cerebral_venous_thrombosis

Cohort studies

http://n.neurology.org/cgi/collection/cohort_studies

Prognosis

http://n.neurology.org/cgi/collection/prognosis

Stroke in young adults

http://n.neurology.org/cgi/collection/stroke_in_young_adults

Information about reproducing this article in parts (figures,tables) or in its entirety can be found online at:

http://www.neurology.org/about/about_the_journal\#permissions

Information about ordering reprints can be found online:

http://n.neurology.org/subscribers/advertise

Neurology ${ }^{\circledR}$ is the official journal of the American Academy of Neurology. Published continuously since 1951, it is now a weekly with 48 issues per year. Copyright (C 2020 American Academy of Neurology. All rights reserved. Print ISSN: 0028-3878. Online ISSN: 1526-632X.

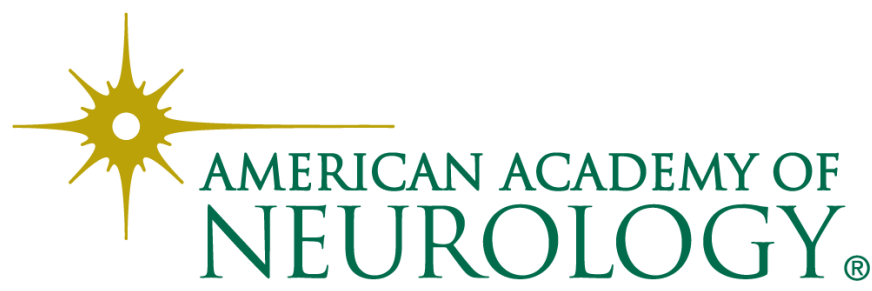

